\title{
LEAN OFFICE AND DIGITAL TRANSFORMATION: A CASE STUDY IN A SERVICES COMPANY
}

\section{Alberto Eduardo Besser Freitag \\ abesser@uol.com.br \\ Centro Federal de Educação Tecnológica Celso Suckow da Fonseca - CEFET/RJ \\ Juliana das Chagas Santos julianachsa@gmail.com}

\section{Augusto da Cunha Reis} professor.augusto.reis@gmail.com Centro Federal de Educação Tecnológica Celso Suckow da Fonseca - CEFET/RJ

\begin{abstract}
- Highlights: a high percentage of the Western world workforce works in offices; Value Stream Map, a lean tool, allows waste identification in services companies; Lean Management helps companies to prepare for digital transformation; there is scarce scientific literature ondigital transformation and Lean Office.

-Goal: thepurpose of this article is to report the implementation of Lean Office and digital transformation in a services company.

- Design / Methodology / Approach:the research method was a qualitative approach, with literature review followed by a case study, and data collected until September 19, 2018.

- Results: the comparative results between current and future Value Stream Maps showed consistent improvements in terms of performance indicators. The lead time is expected to fall from 101 hours to 64,65 hours under normal conditions, and from 221 hours to 114,65 hours if there is a need to bypass through process \# 6 .

- Limitations of the investigation: there are limitations in this study.Basically, the time frame until the digitalization of the processes \# 1, 2, 3 and 6 have been completed, in order to allow the comparison with the original expectations described in the VSM of the future state.

- Practical implications: it was possible to demonstrate how the implementation of Lean principles, techniques, and tools can bring benefits to an loT solutions provider.

- Originality / Value: no records were found on Scopus and Web of Science databases for the search sentence "digital transformation" AND "lean Office", representing a gap to be filled with this study.
\end{abstract}

Keywords: Lean Management; Lean Office; Digital Transformation; Services Company. 


\section{INTRODUCTION}

The origin of Lean is based on manufacturing and shop floor; however, its basic principles are applicable to any part of a company (Kurigeret al., 2010), including Office and administrative processes, known as Lean Office.Tapping and Shuker (2003) estimate that administrative functions represent between $60 \%$ and $80 \%$ of the costs associated with meeting customer demands, when manufacturing a part.

The Office environment is of great importance for the Western world, since several studies show that $50 \%$ to $80 \%$ of the workforce is in the offices (Danielsson, 2013).

The digital transformation of the Office environment is gaining increasing interest by the companies. A lot of factors influence this implementation, which should be done in an iterative manner to ensure the desired results. It is risky, challenging and costly to conduct a digital transformation in all business units and processes simultaneously. Thus, Abolladoet al. (2017) recommend starting with few users and a limited number of activities, acquiring the necessary experience to later expand the digital transformation project for the rest of the organization.

There are few studies dealing with the joint application of Lean Office and Digital Transformation, which reinforces the importance of this work, whose aim is to complement the scarce available literature, describing the good results expected with the digital transformation inthe Operations department of aBrazilian Internet of Things solution provider.

\section{LITERATURE REVIEW}

\section{Lean Office definitions}

The main objective of the Toyota Production System (TPS) is the systematic elimination of seven wastes: 1) Excess of production; 2) Waiting time (manpower, material and process); 3) Unnecessary transport of materials; 4) Inadequate processing; 5) Excess of inventory; 6) Unnecessary movement of manpower and; 7) Corrections or refusals (Ohno, 1997; Hines and Taylor, 2000). Lean thinking, a socio-technical management philosophy inspired by the TPS (Liker, 2004; Shamah, 2013), is about the elimination of waste in the production process that does not add value to the customer, in addition to reducing costs and improving productivity (Silva et al., 2015). It is characterized by five principles defined by Womack and Jones (2003) as being: 1) Value - specifying value from the perspective of the client; 2) Value stream aligning activities in the best sequence to produce a good or service and create this value; 3 ) Continuos flow -performing these activities without interruption; 4) Pull - whenev- er someone requests and; 5) Perfection - in an increasingly effective way.

Lean Office is the application of Lean Thinking principles in administrative areas (Monteiroet al., 2017), aiming to achieve the benefits obtained with Lean Production in information processes (Herkommer and Herkommer, 2006). The difference between Lean Production and Lean Office is that the first has physical flows, allowing good visibility of the work done in a manufacturing plant, while in the second, the flows involve information and knowledge of the employees in the Office (McManus, 2005).

Danielsson (2013) identified two main perspectives in the context of Lean Office design:

1) The neo-Tayloristic Lean Office -the focus is on applying a scientific approach aiming standardization. This involves: a) Maintainingonlythe material directly related to the execution of the workin the workplace, not allowing customization according to the desire of the employee; b) Decisions about the project and its use areof management responsibility, without involvement of employees; c) The attempt is to standardize as much as possible.

2) The team-based Lean Office - the focus is on the concept of the "learning organization" and problem solving in order to reduce lead time. This involves: a) Employees with more autonomy, power, and responsibility at individual and team level (Edwards et al., 2010); b) A supervisor that avoids micromanagement, taking responsibility for the results of the team as a whole; c) Strong relational aspect, i.e. the quality of work depends on relationships, based on clear common goals (Hines et al., 2004) and; d) Leadership is a key factor of success in "learning organizations" (Emiliani, 2008).

\section{Lean Office benefits}

Lean Office was developed based on Lean Thinking concepts, initially applied only on factory floors, and later also in the administrative office environment (Cavaglieri and Juliani, 2016). The successfullapplication in industrial production enabled the adaptation of the use of lean tools in the office environment, agilizingthe management of information and materials, with the elimination of idle procedures thatgenerated waste and thus created more value to the flow of information and administrative processes.

Almeida et al. (2017) cite as benefits of the Lean Office approach that it "allows reducing overproduction of printed documents, cutting the time needed to provide services, re- 
stricting excessive movement of people between sections, improving the use of underused human resources, reducing the number of hierarchical levels and minimising document storage costs" (Scaleraet al., 2012).

McKellen (2005) reported the typical benefits of implementing Lean Office, which can be summarized by Gonçalveset al. (2015) as: a) Effective communication through visual management: use of updated and organized murals, as well as electronic dissemination of information; b) Efficient use of space: elimination of physical file storage areas, as well as the use of online file storage; c) Reduction of crossing time: identification and elimination of delays between departments, as well as elimination of excessive approvals for purchasing office supplies and equipment; d) Reduction in the amount of processed paper: reduction and elimination of printed e-mails for future reference, as well as reducing the amount of copies; e) Formalizing document crossing systems: implementation of standard operating procedures; $f$ ) Reduction of meeting time: early and efficient communication of necessary meetings, which begins and end on time; g) Elimination of internal computer notifications: verification of online data and external terminals and; h) Motivation of the people: use of empowerment.

\section{Lean Office implementation}

The main implementation phases of a Lean Office Project are commonly "1) Lean Event and Project Presentation; 2) Priorities Identification; 3) Pilot Team Identification and; 4) Methodology application. The last phase included the following steps: (i) Team Organization; (ii) Visible Best Practices; (iii) Process Improvement and; (iv) Autonomous Teamwork" (Monteiroet al., 2015).

Value stream, described below, is one of the most implemented Lean tools in Office areas because it brings results quickly:

\begin{abstract}
"Themethodology starts by gathering in a room all relevantactors of the selected value stream, mapping all steps of theprocess (adding value or not) and flow of information. The team then identifies the process tasks that are purewaste and eliminates them in order to reduce thenumber of process steps, reduce lead time, andimprove flow and efficiency. The team alsofinds ways of improving the efficiency of the neededsteps by including low cost automation solutions and "poka-yoke" devices to reduce errors" (Rüttimannet al., 2014)
\end{abstract}

Recent studies available in the scientific literature about the implementation of Lean Office highlight the use of the
Value Stream Mapping (VSM) tool, because it allows the identification and elimination of waste and unnecessary processes, generating winnings in performance and agility (Freitaset al., 2018). Rother and Sook (2003), cited by Silva et al. (2015), encourage the use of VSM, a planning tool that facilitates the visualization of information flows. Almeida et al. (2017) present a proposal of eight steps forthe implementation of VSM in Lean Office:

"1) Committing to change: to conduct communication, allowing experimentation andflexibility in tool application, where support by top management is essential for conductingsuch a change; 2) Choosing the flow of value: to understand the flow of value, create an improvementplan andimprove processes, considering both the flow of value andimprovement plan; 3) Learning about Lean: to understand the concepts and terms associated with Leanthinking through training and creating a learning plan; 4) Mapping the current status: to understand the Lean office concepts and tools as aprerequisite, from the previous steps, to expose workflow and information units byusing a set of symbols and icons; 5) Identifying Lean performance measures: to determine the metrics to help achievethe objectives of Lean thinking, thus promoting continuous improvement andeliminating waste; 6) Mapping the future status: to map the future status to indicate where Lean toolswill be used.It consists of three phases: the understanding phase of the client'sdemands, the implementation phase for continuous flow, so that the value desiredby the client can be established, and the levelling phase (work equallydistributed); 7) Creating Kaizen plans: to develop a continuous improvement plan - Kaizen and; 8) Implementing Kaizen plans: to carry out the Kaizen plan through itsimplementation and follow-up" (Tapping and Shuker, 2003)

\section{Lean and digital transformation}

Marketing specialists are changing the product promotion and marketing plans, because currently they manage more ways to interact with their customers, due to the emergence of new social media platforms. The competition requires that, in addition to understanding "what" happened, organizations ask "how" and "why" it happened and how to ensure this to happen or not again. The complexity and uncertainty of the modern world requires powerful dynamic analysis solutions in real time, since the traditional tools of generic reports do not meet the needs of companies, besides being time-consuming and error-prone. Brockeet al. (2016) cite SAP (2012), a major player of Big Data analytics technologies, which states- 
that "the key is unlocking data to move decision-making from Sense \& Respond to Predict \& Act."

There are similarities between the Lean Management philosophy and improvement strategies applied in organizations. Tay and Low (2017) report the case of a digital transformation in a Higher Education Institution, which evolved from the traditional printed materials to digital formats, simplifying its internal operations and creating value for the teaching and learning community.

Industrie 4.0 or smart factory is an approach of digital transformation in an environment of the internet of things and services, inserted in the current German industrial policy. It is achieved through the integration of information technologies and communication technologies in industrial production. Through digital transformation, innovative technologies are broughtto Lean Production environments, as demonstrated by Wagner et al. (2018), who propose a concept of integration to enhance Industrie 4.0 technologies in industrial value streams, using elements of design thinking.

The adoption of digital transformation is a challenge for companies, reason why the existance of educational institutions is important to support factories to overcome implementation barriers, spreading and speeding the adoption of digital operations technologies through the industrial sectors. A good example is the Textile Learning Factory 4.0, whose goal is to develop hands-on experimental capacity building. One of the key differentiators is the "ability to change between two implementation levels of the process: Level 1 - Current State Operation (Lean) and Level 2 - Future State Operation (Industry 4.0)" (Küsterset al., 2017).

Digital transformation remains an ongoing challenge in construction and facility management applications (Teizeret al., 2017).

\section{METHOD}

Contrasting with research strategies that are based on data collected at first hand (experimental, surveys, field studies), the available data researcher mines second-hand information (Singleton Jr and Straits, 2010). This study adopted a qualitative approach, using available data until September 19,2018 , starting with a systematic literature review in four steps, based on the PRISMA method (Moheret al., 2009) (see Chart 1).

No records were found on Scopus and Web of Science databases for the search sentence "digital transformation" AND "lean Office", representing a gap to be filled with this study.

The second work stage was developed in the company, through a case study, whose main features are (Robson, 2011): a) Selection of a single case of a situation, person or group of interest or concern; b) Case study in this context and; c) Collection of information through a variety of data collection techniques including observation, interview and documentary analysis.

The information was collectedthrough informal conversations with a manager and data analysis from the company. Based on the gathered information, it was definedto start the Lean Office implementation at the Operations department. First, the current state of the value stream map (VSM) was drawn including all involved processes. Second, after analysis and identification of opportunities for waste elimination in the "scheduling" macroflow, a VSM of the future state was developed, to be deployed with the application of Lean principles, techniques, and tools. The third step to be performed is the digitalization of some processes from the VSM to eliminate waste. Results measurement will be accomplished through performance indicators.

\section{CASE STUDY}

The company, object of this study, hereinafter referred to as Brazilian loT (Internet of Things) for reasons of secrecy, delivers loT solutions for large companies, through a plataformthatallows the connection of things, people, data, and processes.

Chart 1. The four steps of the PRISMA method

\begin{tabular}{|c|c|c|c|c|c|}
\hline Database & Searchsentence & 1.Identify & 2.Screening & 3.Elegibility & 4.Included \\
\hline \multicolumn{3}{|c|}{ Exclusioncriteria ============ $\rightarrow$} & $\begin{array}{l}\text { Duplicatedregis- } \\
\text { ters (\# 10) }\end{array}$ & $\begin{array}{c}\text { Text, method or authors } \\
\text { not available (\# 40) }\end{array}$ & $\begin{array}{l}\text { Full-text not aligned } \\
\text { with this work (\# 3) }\end{array}$ \\
\hline Scopus & \multirow{2}{*}{ "lean Office" } & 38 & \multirow{2}{*}{6} & \multirow{2}{*}{15} & \multirow{2}{*}{12} \\
\hline Web of Science & & 11 & & & \\
\hline Scopus & \multirow{2}{*}{$\begin{array}{l}\text { "digitaltransforma- } \\
\text { tion" AND lean }\end{array}$} & 16 & \multirow[b]{2}{*}{4} & \multirow[b]{2}{*}{7} & \multirow[b]{2}{*}{7} \\
\hline Web of Science & & 7 & & & \\
\hline & Total & 72 & 62 & 22 & 19 \\
\hline
\end{tabular}


Brazilian Journal of Operations \& Production Management

Volume 15, Número 4, 2018, pp. 588-594

DOI: 10.14488/BJOPM.2018.v15.n4.a12

\section{RESULTS AND DISCUSSION}

In order to identify waste in Brazilian IoT, the Value Stream Map (VSM) of the current state was initially drawn (see Figure 1), showing the client and main processes involvedin the same diagram, as well as improvement opportunities in "kaizen explosions". The "scheduling" macroflow of the Operations department has been identifiedas the one with the main opportunities for waste removal. The VSM of the future state (see Figure 2) shows the improvement proposals for elimination of the identified waste.

Chart 2 presents a comparison between the current and future state of the Operations department of Brazilian IoT.

The current Value Stream Map (VSM), including the "scheduling" macroflow, comprises five processes and operates under normal conditions with 11 people, with a total processing time of 74 hours and wait time (waste) of 27 hours, thus, with a corresponding lead time of 101 hours. If there is no technician from the Brazilian loT available, then it is necessary to find and negociate with a local provider (process \#6), which delays the whole operation, increasing the total processing time to 146 hours, wait time (waste) to 75 hours and corresponding lead time to 221 hours.

The future VSM shows the digitalization of processes \# 1 , 2, 3 and 6, thus, expecting the productivity increase of the Operations department, falling to a total lead time of 64,65 hours under normal conditions and 114,65 hours if there is a need to bypass through process \# 6 .

\section{CONCLUSION}

Lean Office, based on the Toyota Production System, is an alternative to increase productivity incompanies and make them more competitive, with respect to cost, quality, deadlines, and waste elimination. A case study was developed in an loT solutions provider located in Brazil, and it was possible to demonstrate how the implementation of Lean principles, techniques and tools can bring benefits to the Operation department. The value stream map (VSM) in the current and future state allowed the identification of waste in the "scheduling" macroflow, which will be attacked by the use of digital devices. Despite the expected positive results with the digital transformation, there are limitations in this study; basically, the time frame until the digitalization of the processes \# 1, 2, 3 and 6 will be implemented, thus allowing the comparison with the original expectations described in the VSM of the future state.

\section{REFERENCES}

Abollado, J. R.; Shehab, E.; Bamforth, P. (2017), "Challenges and Benefits of Digital Workflow Implementation in Aerospace Manufacturing Engineering", Procedia CIRP 60, pp. 80-85.

Almeida, J. P. L.; Galina, S. V. R.; Grande, M. M.; Brum, D. G. (2017), "Lean thinking: planning and implementation in the public sector", International Journal of Lean Six Sigma, Vol. 8, No. 4, pp.390-410.

Brocke, J. V.; Fay, M.; Böhm, M.; Haltenhof, V. (2016), “Creating a Market Analytics Tool that Marketers LOVE to Use: A Case of Digital Transformation at Beiersdorf", in Oswald, G.; Kleinemeier, M. (Ed.), Shaping the Digital Enterprise.

Cavaglieri, M.; Juliani, J. P. (2016), "LeanArchives: O emprego do Lean Office na gestão de arquivos", Perspectivas em Ciência da Informação, Vol.21, No.4, pp.180-201, out./dez.

Danielsson, C. B. (2013), "An explorative review of the Lean office concept", Journal of Corporate Real Estate, Vol. 15, No. 3/4, pp. 167-180.

Edwards, K.; Bojesen, A.; Paarup Nielsen, A., eds. (2010), Lean ogarbetsmiljoe - ettdynamisktspaendningsfelt (Eng. Lean and Work Environment - A Dynamic Tension). L\&R Business Egmont, Denmark.

Emiliani, B. (2008), Practical Lean Leadership: A Strategic Leadership Guide for Executives. The Center for Lean Business Management (The CLBM), LLC, Wethersfield, CT.

Freitas, R. C.; Freitas, M. C. D.; Menezes, G. G.; Odorczyk, R. S. (2018), "Lean Office contributions for organizational learning", Journal of Organizational Change Management, Vol. 31, No. 5, pp. 1027-1039.

Gonçalves, V. K. A.; Melo, D. R. A.; Viana, A. L.; Medeiros, S. H.S. (2015), "Lean Office:Estudo da Aplicabilidade do Conceito em uma Universidade Pública Federal", Espacios, Vol. 36, No. 18, pp. E-1.

Chart 2. VSM comparison at Operations department

\begin{tabular}{|c|c|c|c|c|c|}
\hline VSM & $\begin{array}{c}\text { Processing time (hs) } \\
\text { Value-add }\end{array}$ & $\begin{array}{c}\text { Wait time (hs) Not } \\
\text { Value-add }\end{array}$ & Lead time (hs) & \# Process & \# People \\
\hline Current & $74-146$ & $27-75$ & $101-221$ & 6 & 11 \\
\hline Future & $37,65-61,65$ & $27-53$ & $64,65-114,65$ & 6 & 11 \\
\hline
\end{tabular}




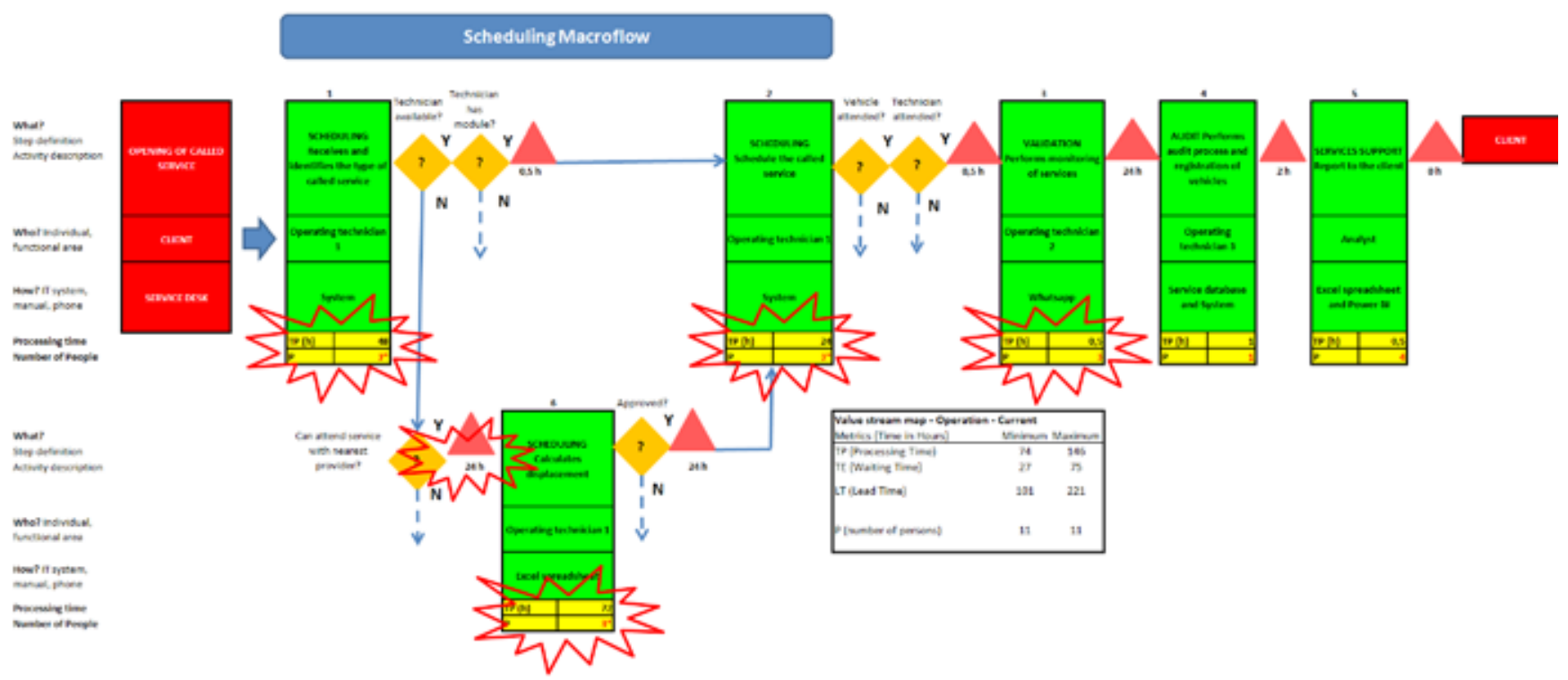

Figure 1. VSM at Operations department - current state Source: The authorsthemselves (2018)

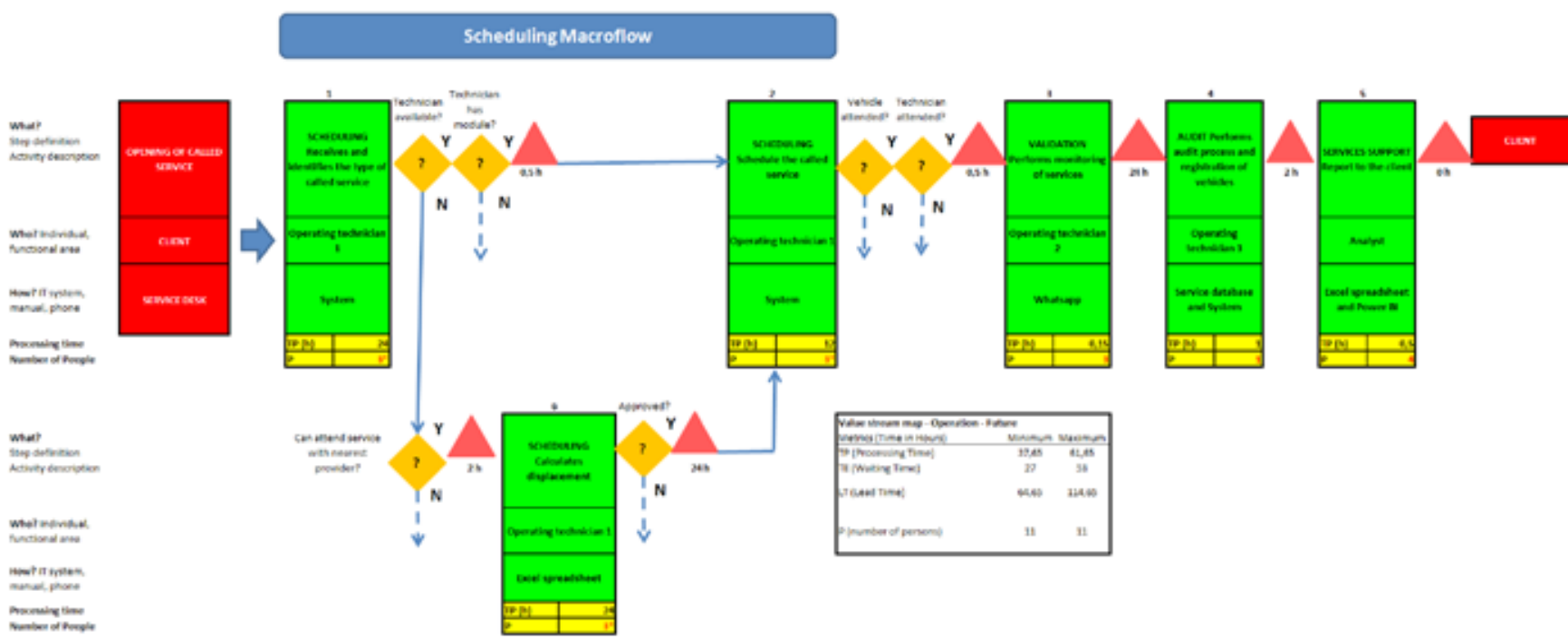

Figure 2. VSM at Operations department - future state Source: The authorsthemselves (2018)

Herkommer, J.; Herkommer, O. S. (2006), ZeitschriftfuerWirtschaftlichenFabrikbetr, Vol. 101, No. 6, pp. 378-381.

Hines, P.; Holweg, M.; Rich, N. (2004), "Learning to evolve: a review of contemporary lean thinking", International Journal of Operations \& Production Management, Vol. 24, No. 10, pp. 994-1011.

Hines, P.; Taylor, D. (2000), Going Lean: A Guide to Implementation, Lean Enterprise Research Center, Cardiff.

Kuriger, G. W.; Wan, H-d.; Mirehei, M.; Tamma, S.; Chen, F. F. (2010), "A Web-Based Lean Simulation Game for Office
Operations: Training the Other Side of a Lean Enterprise", Simulation \& Gaming, Vol. 41, No. 4, pp. 487-510.

Küsters, D.; Praß, N.; Gloya, Y-S. (2017), “Textile Learning Factory 4.0 - Preparing Germany's Textile Industry for the Digital Future", Procedia Manufacturing 9, pp. 214-221.

Liker, J. K. (2004), The Toyota Way: 14 Management Principles from the World's Greatest Manufacturer, McGraw-Hill, New York, NY.

McKellen, C. (2005), "The lean Office”, MWP- Metalworking Production, Vol. 149, No. 9. 
McManus, H. (2005), Product development value stream analysis and mapping manual (PDVMS). The Lean Aerospace Initiative: Massachusetts Institute of Technology.

Moher, D.; Liberati, A.; Tetzlaff, J.; Altman, D. G.; The PRISMA Group. (2009), "Preferred Reporting Items for Systematic Reviews and Meta-Analyses: The PRISMA Statement", PLoS Med, Vol. 6, No. 7, e1000097.

Monteiro, J.; Alves, A. C.; Carvalho, M. S. (2017), "Processes improvement applying Lean Office tools in a logistic department of a car multimedia components company", Procedia Manufacturing 13, pp. 995-1002.

Monteiro, M. F. J. R.; Pacheco, C. C. L.; Dinis-Carvalho, J.; Paiva, F. C. (2015), "Implementing Lean Office: A Successful Case in Public Sector", FME Transactions 43, pp. 303-310.

Ohno, T. (1997), O Sistema Toyota de Produção: além da produção em larga escala, Artes Médicas, Porto Alegre.

Robson, C. (2011), Real World Research: a resource for users of social research methods in applied settings. 3rd Ed. West Sussex: John Wiley \& Sons, Ltd.

Rother, M.; Sook, J. (2003), Learning to See: Value Stream Mapping to Add Value and Eliminate Muda, The Lean Enterprise Institute, Cambridge, MA.

Rüttimann, B. G.; Fischer, U. P.; Stöckli, M. T. (2014), “Leveraging Lean in the Office: Lean Office Needs a Novel and Differentiated Approach", Journal of Service Science and Management, Vol. 7, pp. 352-360.

SAP (2012), SAP predictive analysis. Transforming the future with insight today. BI Global Center of Excellence. Available via SlideShare:http://www.slideshare.net/IvervandeZand/ sap-predictive-analytics/ (Accessed 11 Apr 2015).

Scalera, F.; Dumitrescu, C.; Talpová, S. Z. (2012), “International crisis and competitiveness of service companies and public administration in Italy and in Europe: the application of lean Office", Business and Management Review, Vol. 2, No. 1, pp. 63-75.

Shamah, R. A. M. (2013), "A model for applying lean thinking to value creation", International Journal of Lean Six Sigma, Vol. 4, No. 2, pp. 204-224.

Silva, I. B. da; Seraphim, E. C.; Agostinho, O. L.; Junior, O. F. L.; Batalha, G. F. (2015), "Lean office in health organization in the Brazilian Army", International Journal of Lean Six Sigma, Vol. 6, No. 1, pp. 2-16.

Singleton Jr, R. A.; Straits, B. C. (2010), Approaches Social Research, 5th Ed., Oxford University Press, Inc., chapter 12, pp. 393-430.

Tapping, D.; Shuker, T. (2003), Value Stream Management for the Lean Office: Eight Steps to Planning, Mapping, and Sustaining Lean Improvements in Administrative Areas, Productivity Press, New York, NY.

Tay, H. L.; Low, S. W. K. (2017), "Digitalization of learning resources in a $\mathrm{HEI}$ - a lean management perspective", International Journal of Productivity and Performance Management, Vol. 66, No. 5, pp.680-694.

Teizer, J.; Wolf, M.; Golovina, O.; Perschewski, M.; Propach, M.; Neges, M.; König, M. (2017), "Internet of Things (IoT) for Integrating Environmental and Localization Data in Building Information Modeling (BIM)", 34th International Symposium on Automation and Robotics in Construction (ISARC 2017).

Wagner, T.; Herrmann, C.; Thiede, S. (2018), “Identifying target oriented Industrie 4.0 potentials in lean automotive electronics value streams", Procedia CIRP 72, pp. 1003-1008.

Womack, J. P.; Jones, D. T. (2003), Lean Thinking, Free Press, New York, NY.

Received: 08 Oct 2018

Approved: 19 Oct 2018

DOI: 10.14488/BJOPM.2018.v15.n4.a12

How to cite: Freitag, A. E. B.; Santos, J. C.; Reis, A. C. (2018), "Lean Office and digital transformation: a case study in a services company", Brazilian Journal of Operations \& Production Management, Vol. 15, No. 4, pp. 588-594, available from: https://bjopm.emnuvens.com.br/bjopm/article/view/579 (access year month day). 